\title{
Speak with one voice! Towards an ecumenical ethics applicable to the church-state dialogue in South Africa
}

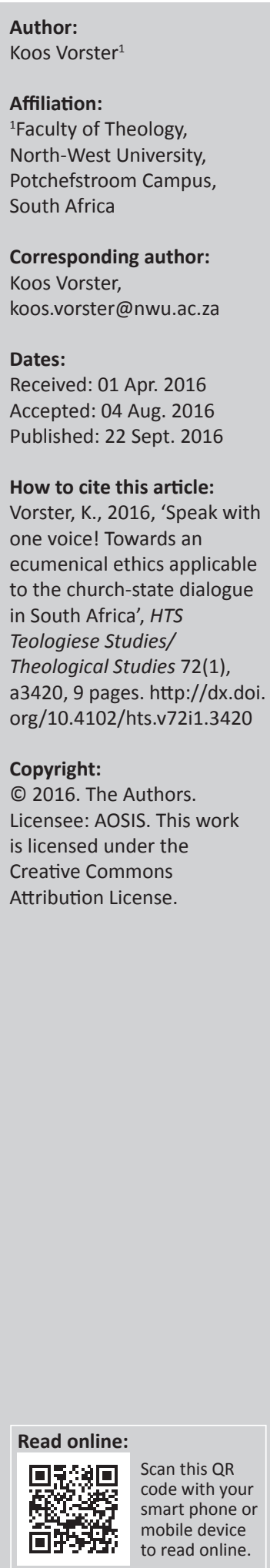

This research deals with the question of whether an ecumenical ethics can be developed in South Africa that at least will be applicable in the field of political ethics and that can assist the various ecclesiastical traditions to 'speak with one voice' when they address the government on matters of Christian ethical concern. The research rests on the recognition of the variety of ethical persuasions and points of view that flow from the variety of hermeneutical approaches to Scripture. However, within this plethora of ethical discourses, an 'overlapping' ethics based on a proposed set of minimum theological ideas can be pursued in order to reach at least an outline of an applicable ecumenical political ethics conducive to the church-state dialogue in South Africa today. The article concludes that a 'minimum consensus' on the role of revelation in the moral discourses is possible and is enriched by traditional ideas such as creation and natural law, the reign of God and Christology, and it can provide a suitable common ground for an ecumenical ethics applicable to the moral difficulties in the political domain in South Africa today.

\section{Introduction}

This research article was inspired by two personal experiences of witnessing to the South African government of the day on Christian ethical matters as a member of a church delegation. The first occasion was in 1981 when the Reformed Churches in South Africa (known as the GKSA) resolved to discuss with the then government the moral foundation of the security laws. The GKSA was of the opinion that the laws as they were promulgated and applied at the time to suppress the resistance against Apartheid were morally unjustified and should be reviewed. However, other churches and theologians supported the government's strong stand in favour of a forceful maintenance of law and order in view of the escalation of violence against the system and the spread of the war of liberation across the borders of the country. The author was present when Pres. P.W. Botha lamented the fact that the churches did not agree on this issue and that these differences made it difficult for the government to take the concern of the GKSA seriously. He reprimanded the churches to 'speak with one voice'.

The second experience was in 2005, when the author was instructed by the GKSA to submit a presentation before a Parliamentary Commission on the issue of the amendment of the Marriage Act (Act no. 25 of 1961) to include 'same-sex marriages'. Various churches submitted presentations with different and even conflicting opinions and recommendations. Again the chairman of the Commission bemoaned the lack of agreement between the ecclesiastical traditions and theologians on this particular issue and opined that the divergent and conflicting opinions of churches hampered the willingness of the government to take the testimony of churches seriously. Eventually, the Government of the Republic of South Africa (RSA) promulgated the Civil Unions Act (Act no. 17 of 2006), which made provision for the formation of civil unions of gay couples. The protest of many churches was rejected owing to the divergence of opinions and conflicting ideas in ecclesiastical circles.

These experiences raised the question of whether an ecumenical ethics can be developed in South Africa that will at least be applicable in the field of political ethics and that can assist the various ecclesiastical traditions to 'speak with one voice' when they address the government on matters of Christian ethical concern. Ethics is deeply rooted in hermeneutics (see Fairfield 2002:131). The various contemporary theories of interpretation in theological discourses therefore have a

Note: This work is based on the research supported by the National Research Foundation (NRF). Any opinion, finding and conclusion or recommendation expressed in this material is that of the author and the NRF does not accept any responsibility in this regard. 
huge impact on the definition of biblical moral codes (Long et al. 1996). Ethicists subsequently have to agree that total consensus on moral directives for the political domain is impossible, as the numerous moral discourses in Christian ethics today testify. Huber (2011:429) even asks the question whether Christian ethics still matters in this pluralistic world. However, having listened to these arguments, the following question can still be asked: Can sufficient overlapping moral consensus $^{1}$ be achieved to assist the churches in their prophetic task towards the government with the moral development of the South African society as the objective?

This article investigates such a possibility. The research rests on the recognition of a variety of ethical persuasions and points of view that flow from a variety of hermeneutical approaches to Scripture. Within this plethora of ethical discourses, an 'overlapping' ethics based on a proposed set of minimum theological ideas can be pursued to draw an outline of an applicable ecumenical political ethics conducive to the church-state dialogue in South Africa today. The central theoretical argument of this article is that a 'minimum consensus' on the role of revelation in the moral discourse is possible and, enriched by traditional concepts such as creation and natural law, the reign of God and Christology, it can provide a suitable common ground for an ecumenical ethics applicable to the political domain (see Hadsell 2006:19).

Therefore, the first and foremost question to deal with is: How do we view Scripture as the foundation of Christian faith and lifestyle? This question is valid and of utmost importance because it is exactly the position of Scripture that has come under scrutiny in the last three centuries. Divergent views of Scripture have led to divergent views of morality and divergent views of the essence of Christian witness in the political domain. Can we find a common ground in our different views of the authority of Scripture in our search for an ecumenical ethics applicable to the church-state debate in South Africa? In an effort to answer this question, the various views of Scripture are defined briefly with the aim to find some common ground that can serve as a hermeneutical precondition for a South African ecumenical ethic.

\section{Scripture ${ }^{2}$}

Since the enlightenment, many different modernist views on Scripture have emerged and these resulted in an ongoing debate about the theories of interpretation of the

\footnotetext{
1.The term 'overlapping consensus' was first used by Rawls (1993:134) in anothe context. Although Rawls does not deal with ethics, but with political philosophy, one context. Although Rawls does not deal with ethics, but with political philosophy, one
can derive from his point of view that his solution to the problem of political
plurality can also be applicable to ecumenical ethics. To solve the problem of plurality can also be applicable to ecumenical ethics. To solve the problem of
pluralism in a democratic society, Rawls proposes the idea of 'overlapping consensus'. In his view, a well-ordered society needs an overlapping consensus that allows for a plurality of reasonable, although opposing, comprehensive doctrines, each with its own conceptions of the good (see also Vorster 2010:595). A wellordered society can be stable when a political concept of justice can be offered that every supporter of a reasonable doctrine can endorse from their own philosophical, ideological or moral point of view. The question at hand is whether the Christian ethicist can also speak of an 'overlapping consensus' when pursuing the idea of an ecumenical ethic.

2.The author discussed the hermeneutics of Christian Ethics in another publication (see Vorster 2014:37-101). Some of the material regarding the theoretical framework used in that publication are also presented in this article but are then, amongst others, applied afresh to the issue of ecumenical testimony by churches in South Africa today.
}

biblical text(s). Post-modernism added other views on the Scripture and stimulated the hermeneutical debate. While modernism questioned the divine authority of Scripture, post-modernism questions any possibility of a single clear explanation of biblical texts (Van den Brink \& Van der Kooi 2012:488). The classic idea of the Scripture as the Word of God as it was entertained for centuries in the Roman Catholic, Orthodox and Protestant traditions is viewed with suspicion (McGrath 2008:68).

The classic confessions, which teach the authority of Scripture, was first challenged by the various schools in the historical-critical study of Scripture initiated by Baur (1792-1860), other members of the Tübingen School and Wellhausen (1844-1918). These were followed by many divergent critiques of the notion of the divine authority, unity and the historical reliability of Scripture. Bruce (1988:93) explains the diverse points of departure and the directions of these schools. He analyses, among others, textual criticism, literary and historical criticism, tradition and form criticism, redaction criticism, canon criticism and structuralism. This investigation does not enter into a discussion of these schools. Such discussions have been done by many scholars in the field of hermeneutics (see Dunn 2003:68; Long et al. 1996). It would be sufficient to say that the biblical criticism of the German Enlightenment brought about a new approach to Scripture and this approach had a dynamic influence on the Christian idea of the Bible as foundation of faith and life.

However, because of its immense influence on the later development of Historical Criticism, the theory of Bultmann (1884-1976) and his school of thought has to be explained. In this paradigm, called Form Criticism, it is argued that the biblical text cannot be regarded as the Word of God, as the classic traditions explained, but rather that the Word of God is 'in the biblical text'. This idea became an important viewpoint in the determination of the 'message of the Bible for a modern world'. As was done in the many schools of biblical criticism, Bultmann and his followers questioned the historicity of the biblical texts and concluded that the gospels contain almost no authentic historical information about Jesus, but rather material shaped and frequently created by the early Christian communities (Bultmann 1963). This fact must in their view be the foundation of any theory of biblical interpretation. This point of departure led to the theory that the biblical text must be cleared of its mythical character and that the exegete should excavate the real message from the original historical and cultural context. Bultmann developed an own theory and he defined this theory as the 'demythologising' of Scripture. With this concept, he explains the process of interpreting mythology consistently in terms of the understanding of human existence that it articulates. The theologian should distinguish between the essence of Christian faith and an obsolete supernatural worldview that is no longer available to us. He maintained that in such a way the existential meaning of the Christian faith can be discovered (Bultmann 1967). Dunn (2003:73) argues that Barth (1886-1968) rang the death bell for Liberal Protestantism with his view that biblical criticism can deal only with the 
words of the biblical author, but cannot get to the Word of God within these words, although Barth admitted that historical criticism has its rightful place.

However, in spite of Barth's acclaimed criticism of this position, Bultmann's view was very influential and inspired a way of exegesis where the real contents of Scripture are distinguished from the form. The exegete has to decompose the real message of Scripture from the wide range of literary forms, cultural beddings and socio-historical backgrounds. For this purpose, socio-historical research became a prerequisite for biblical exegesis. Virtually all exegetical traditions, except those who opt for a theory of verbal inspiration of Scripture and its infallibility, nowadays acknowledge the necessity to read the text within the historical context. Differences arise on how far the process of 'demytholising' can go. Modern-day discourses in exegesis focus on the question: 'What is the inherent message of the text(s) and what should be regarded as part and parcel of the obsolete socio-historical context of the text(s)?' In some circles, the whole idea of a 'biblical ethic' is questioned owing to the point of view that all ethical codes of Scripture are determined by the socio-historic context and can therefore have no bearing on modern life (see Muller 2002; Van den Brink \& Van der Kooi 2012:494).

Post-modern biblical interpretation deviated from the historical criticism in the sense that any claim to neutrality and objectivity in the readers' approach to Scripture should be questioned. Late 20th century philosophers such as Gadamer (1976), Ricoeur (1981) and Derrida (1997, 2004) debated, from different angles, communication theory and the quest for deconstruction of language, the function of context in the interpretation of texts and the role of subjectivity and pre-judgement in understanding. In addition to these new theories of interpretation, Kuhn (1970) and Lyotard (1991, 2004) maintained that all approaches in scientific method depart from certain assumptions and presuppositions. The assumptions and presuppositions determine the findings of research. Therefore, truth is relative and conditional and no one can claim to have found an objective and certain truth nor can the ethicist define absolute moral codes applicable to all times and places. Their points of view became highly influential in the new theories of the interpretation of the biblical text and the quest for a biblical ethic (Van den Brink \& Van der Kooi 2012:494).

Where historical criticism emphasised the importance of the historical context of the text, post-modernist theories of interpretation added that the context of the present reader should be regarded as equally important in understanding the text. Because of the various assumptions and presuppositions of present readers, exegetical outcomes will differ. These can then not be distinguished as true or false, but merely as valid and 'also valid'. Different outcomes can be acceptable in reading the biblical text. Influential nowadays is the 'hermeneutics of suspicion', a phrase coined by Ricoeur (1981:6-8, 34) in his notorious discussions of the challenges posed by the science of interpretation and the role of ideology (see also Herholdt 1998:451; Stewart 1989:296). The various theories of interpretation in the development of hermeneutics are accepted by many contemporary theologians and they question the plausibility of the classic Reformed notion of divine authority and inspiration of Scripture, as well as the Barthian idea of a biblical theology based on the revelation of God in Jesus Christ (Barth 1932:114). Because of their philosophical understanding of the preconditions for interpretations of the Scripture and their strong emphasis on decontextualising the text, these theologians question the feasibility of a 'Biblical ethic' for a modern society (see Desilet 2009:152; Knight 2003:311).

The development of the science of biblical hermeneutics has led to a variety of approaches to the biblical text and has resulted in different and even opposing views on biblical ethics. This state of affairs is the reason why churches differ in their testimonies to the government of the day. They cannot 'speak with one voice' to the government and society at large because they do not 'speak with one voice' in their various explications and applications of Scripture. This fact should be acknowledged. However, one can still ask: Can they come to a sufficient consensus? Can a common ground be found on important ethical issues in such a way that an ecumenical ethic can be developed? What will such an ethic entail? To my mind, the post-modernist theories of interpretation render such a consensus possible owing to its criticism of notions such as positivism, neutrality and objectivity, and the recognition of the validity of more than one approach. Furthermore, such a consensus comes to light when the ethical significance of some of the major ideas of traditional Christian faith is taken into account. These ideas are the general revelation of God, creation, the reign of God and Christology. In the next sections, the consequences of these topics are investigated.

\section{The idea of the general revelation of God}

In the Reformed tradition since Calvin, the doctrine of the revelation of God in the Book of Nature has been a much debated issue. This is owing to Calvin and his contemporaries' use of the Roman Catholic concept 'natural law' (Calvin 1559:2:2:15; see also Grabill 2006; VanDrunen 2010, 2014; Witte 2007). This view entertained the idea that God revealed himself to all human beings in his creation and in his sustenance of creation. He reveals himself in history and tradition (Van den Brink \& Van der Kooi 2012:174). As part of his revelation in creation, God bestowed humans with a moral inclination and a sense of religion. The reason for these creational gifts is to maintain order in society and to prevent the world from falling into total chaos. His general revelation is then complemented by his particular revelation in Scripture and in Christ. The particular revelation serves the purpose of indicating the way to salvation and knowing God's plan for the renewal of creation.

The doctrine of the general revelation of God again became a discourse in the Reformed tradition in the twentieth century 
because of the well-known and influential debate between Brunner and Barth about 'natural law' (Brunner \& Barth 1946). Barth questioned the usefulness of natural law in the Reformed tradition and his criticism against the background of the natural theology of the 'Reichskirche', as a theological basis for National Socialism, became very influential. As a result, interest in the concept faded. However, in recent times, many scholars in this tradition are re-visiting this concept in order to use it as a moral basis for social life and law. Arner (2016) describes this new interest as follows:

Paul Ramsey proposes to renew, reshape and redirect the natural law, while Ian Ramsey aspires to rehabilitate it, Frederick Carney to revive it, John Macquire to rethink it, Arthur Holmes to reform it, Nigel Biggar to re-approach it, John Bowlin to reinterpret it, Carl Braaten to reclaim it, J. Daryl Charles and Alister McGrath to retrieve it, various Lutherans to reappraise it; several evangelicals to reconsider it, and David VanDrunen to recover and to reform it. (p. 2)

This quotation underscores the current popularity of the concept 'natural theology' in Reformed and Evangelical theological circles today.

General revelation is a core concept in virtually all theological traditions. The new interest in the concept of general revelation and natural law nowadays can therefore be welcomed, especially when dealing with the questions at hand in this article. The idea of natural law paves the way for identifying common ground in defining moral codes in a pluralist world. First of all, this concept, which claims that every human being has a moral inclination, paves the way for an ecumenical and inter-religious social ethic and an understanding of the 'common good'. People can make good laws, can produce influential pieces of art and can contribute to the moral development of societies. Therefore, an ecumenical ethic can draw on the sources and research of history, natural sciences and traditions. However, for Christian ethics, the testing stone would always be the ethic of the main thrust of Scripture and the ethic of Christ. Ethical codes formulated on the basis of the creational gifts of all people cannot contradict the ethic of Scripture and Christ. For example, when religious persuasions proclaim the inherent inferiority of women in society, Christian ethics cannot entertain such an ethical code because of the fact that such a persuasion contradicts the ethic of Christ, which preaches the basic equality of all people in all relations (Gl. 3:28; see Vorster 2007:185).

General revelation and people's creational gifts on the basis of natural law can therefore be seen as an important source of ethical decision-making that can be utilised by various persuasions, religions and theological traditions. Christian churches should not hesitate to enter the pluralist religious domain in search of useful and applicable moral codes in their task of witnessing to the state and society at large. They should also draw on the insights of philosophical schools and traditions, because these moral insights are in the end gifts from God emanating from his general revelation. Among these ethical codes, one can mention the value of life, respect for others, the pursuit of happiness, responsibility, the quest for peace, the judicial responsibility of the state and the moral development of society. In South Africa today, such an interreligious and ecumenical testimony to the authorities can enhance the moral improvement of a community plagued by the vestiges of racism, xenophobia, corruption and the abuse of power. Religions and philosophies can also offer a joint moral foundation for the development of economic policies that are aimed at the effective struggle against poverty. Religions and philosophical traditions have suitable common grounds for the formulation of a social ethic advantageous to the moral development of the South African society.

\section{The idea of creation}

The idea of creation is entertained in all the Christian traditions, while differences occur on the means and duration of creation. However, the doctrine of creation is debated today in view of the scientific findings of palaeontology, physics and evolutionary biology. This discourse results in many different and even conflicting ideas about how God created. However, two aspects of the doctrine of creation that are highly esteemed in all Christian and ecclesiastical traditions are the creation of humans in the image of God (imago dei) and the command of God to humans to act as stewards of creation. These two ideas have a tremendous influence on Christian ethics, because they have a bearing on how humans should treat each other and creation (ecology).

The concept imago dei constitutes the basic dignity of people. Human dignity is a gift from God. In the 20th century after the atrocities of the two world wars, theologians began to draw attention to the importance of the acknowledgement of the basic human dignity of people as a result of God's creational gifts (Barth 1961:116; Berkhouwer 1957:34, 356; Moltmann 1993:2210; Pannenberg 1977:13; Westermann 1973:103; Wright 2004:119). This dignity has its roots also in God's gift to people of 'the breath of life', as explained by the biblical concept nefesj. The word nefesj in the Old Testament means 'life' - the life of human beings as well as animals (see Gn. 1:20; Lv. 17:11; Dt. 12:23). Life comes from God. Brueggemann (1999:51) has said in this regard, 'God's very life is then breathed into the sinner; something of God's own self becomes an integral part of human identity, enabling life to move from God out into the larger world'. This life is more than biological life. Human beings receive spirit - a spirit that does not seize with biological death, but that continues to exist after biological death in the presence of God (see Pss. $16: 10 ; 86: 13 \& 89: 49$ ). Therefore, the concept 'life' is important in any theological reflection (Wüstenberg 1996:136). Unlike animals, human beings are created in the image of God, which entails a special relationship with God and with each other. Humans have a special status before God.

Humans have an inherent dignity and this value forms the basis of all relationships - the relation with God and interpersonal relations. These created relationships are the foundation of human dignity. Human dignity as a creational gift entails that human beings must treat each other with 
respect and that human life is sacred and should be protected. Human dignity as the fruit of the creation of humans in the image of God and the bestowal of the breath of God, should direct human relations and the regulation of society. Therefore, human dignity can be regarded as the foundational value of the common good. In the organisation of society, the concept of human dignity is utilised in the development of an ethos and practice of human rights. The Christian concept of human dignity has the ability to cherish and develop the moral foundation of the quest for human rights. Human rights have become the most important ethical issue in Christianity in modern times (Martinez 1986:270). The same is true of other religions. Virtually all faiths and ideologies found human rights in the concept of human dignity and the morals flowing from this idea. Because of its high valuation of human dignity as a creational gift from God, Reformed moral teaching should be involved, along with other faith traditions and ideologies, in the world-wide process of nurturing human dignity and in the promotion of the cause of human rights everywhere. Human dignity as the foundation of the struggle for the recognition and implementation of human rights should subsequently be seen as a core value of a possible ecumenical ethic.

With the inception of the Universal Declaration of Human Rights in 1948, the idea of human rights and the constitutional state took root and influenced many societies for the better. People come to realise that, 'The human rights violations of today are the wars of tomorrow' ${ }^{3}$ Abuses of people and violations of fundamental human rights cause strife and wars as the great wars of the early 20th century proved. However, churches in South Africa are not as involved in the rejection of violence as a means to promote change and in the furthering of human rights as they should be. Some are even part of the problem, as Olivier (2011) indicates. Much still has to be done by churches to create responsiveness in civil society and state institutions in South Africa for the promotion of the fundamental human rights of people in structures where abuses and violations of human rights are endemic. With a rich theological tradition regarding the calling of Christians in the public sphere against the background of natural law and human dignity, Christian churches can raise awareness of the dignity of humans and fundamental rights of every person and consistently call on the government and civil institutions to honour and protect these rights. In this respect, churches can draw on an ecumenical ethic owing to the fact that the promotion of human dignity is a core principle in all ecclesiastical traditions in South Africa.

Three problems in the public domain related to the Christian concept of human dignity can be identified as problem areas in the current South African context. These are racism, xenophobia and sexism. Race relations in South Africa have improved since the inception of democracy in 1994. De iure racism has been phased out with the inception of constitutional democracy. Reconciliation and transformation had positive effects because of the initiatives of the Truth and
Reconciliation Commission and the efforts of the successive administrations since 1994. However, in spite of these laudable developments, South Africa is still far from a nonracial and reconciled community nation and is still dealing with de facto racism. Racist attitudes are still prevalent in the form of emotion, feeling and bias, as defined by Marger (1994:452). This form of racism is still alive in schools, universities, labour unions and even churches as the current arduous debates on social media about the surge of racism reveal. What is needed is a comprehensive approach by religion, civil society and the government to educate and equip society to root out all prevailing pockets of racist ideas and behaviour. In this respect, Christian churches with their common consent on human dignity and human rights can speak 'with one voice' on the basis of an ecumenical ethic.

The same is true of the voice of churches against xenophobia in South Africa. Xenophobic attacks have plagued this society since 2008. Foreigners who entered South Africa, be it legally or illegally, are blamed by South Africans of 'stealing' the locals' jobs by working for less than the minimum wages in corporations, industries, mines and on farms. They are also accused of manipulating small businesses in townships by benefitting other foreigners to the detriment of local business people. A wave of anti-foreigner sentiment among local South Africans in townships resulted in two waves of serious violent attacks in 2008 and 2015 on foreign businesses when many businesses were looted and burned down. As early as 1999, the South African Human Rights Commission took a strong position against any form of xenophobia. The Commission has stated, inter alia, that xenophobia is a deep dislike of non-nationals by nationals of a recipient state and its manifestation is a violation of human rights. Furthermore, the Commission urged South Africa to send out a strong message that an irrational prejudice and hostility towards non-nationals is not acceptable under any circumstances. Criminal behaviour towards foreigners cannot be tolerated in a democratic society. The Commission also stated that South Africans should seek to construct a society where human dignity, the achievement of equality and the advancement of human rights and freedoms are abiding values. The Bill of Rights confers certain rights to 'everyone'. These are rights to equality, human dignity; the right to life, freedom and security of person; and the right not to be subjected to slavery, servitude and forced labour (South African Human Rights Commission 1999:133). The struggle against xenophobia and the nurturing of an ethos of respect and fundamental human rights is another area where churches should speak with one voice, not only to the authorities on all levels but also to mobilise civil society on the basis of a mutual consensus to become active in this respect.

In addition, the South African society is still plagued by violations of the fundamental rights of women and girl children. In many respects, they are treated as inferior in cultural, family and social life. Although this inferiority is no longer entrenched in social institutions owing to the constant efforts of the ANC government to rectify this form of 
discrimination, sexism is still very much alive in patriarchal families and in churches. Furthermore, women are the victims of poverty more often than men because of migrant labour and joblessness of their male companions. What is even more disturbing is the negative role of religion in the prevailing inferior position of women. Schüssler-Fiorenza (1998:23) had asserted two decades ago that religion played and is still playing a major role in the establishment and continuation of this inferior position of women in societies. This point of view has been reaffirmed by Gudorf (2007). Their observations are still true of society in Africa and South Africa today. Banda (2005:172) has explained that there has been an explosion of newer Christian churches in Africa whose members comprise mainly women. He laments the fact that in these movements the translation and interpretation of religious texts have often resulted in women being told that it is their duty to submit themselves to their husbands or partners. Banda's view can also be applied to some churches that maintain that women can have no leadership positions in churches.

South Africa has made great strides in the recognition of the role of women in government and business and the present administration can be commended for their advancement of the fundamental rights of women in the social sphere. However, religions and religious institutions fall short in this regard. If religion teaches society that women are inferior, the advancement of the rights of women in all spheres of life will be in vain. An ecumenical ethic should pursue the liberation of women. Churches have to promote the fundamental rights of women by initiating and promoting a thorough and far-reaching ecumenical discourse on gender and gender relations. An ecumenical ethic should specifically address the tenability of patriarchal family relations and the androcentric definitions of the role of women in family life and in ecclesiastical institutions. Churches differ on the issue of gay rights. Some acknowledge the right of gay people to enter into an official civil union. Others do not, owing to a more conservative theory of the interpretation of Scripture. However, an ecumenical ethics should call for the recognition of the human dignity and human rights of gay people wherever these are violated in civil relations and should reject all forms of homophobia.

The theology of creation also implies a certain approach to the ecology. Ecocide, as a very disturbing modern ethical problem, has become a widely discussed issue in Christian ethics in virtually all the Christian traditions. This is evident in various statements of ecumenical bodies inter alia the documents of the World Council of Churches (2016:1), the 1987 encyclical of the Pope entitled 'On social concern', and the Evangelical Lutheran social statement entitled 'Caring for creation' (see Granberg-Michaelson 1994:96). Many documents regarding the ecological crisis have also been issued in the sphere of Eastern Orthodox tradition (Efthimiou 1994:2). These documents and the views of many contemporary ethicists challenge humankind to move beyond 'anthropocentrism' (or 'homocentrism') in dealing with creation to 'ecocentrism', which acknowledges humankind's interconnectedness and mutual interdependence with creation (McCormick \& Connors 2002:239).

The biblical perspectives regarding human responsibility towards creation boil down to a theocentric approach rather than an anthropocentric or an ecocentric approach. A theocentric approach entails that caring for the ecosystems should be part and parcel of religion. According to McCormick and Connors (2002:222), three models regarding the relation between humankind and creation can be discerned in Christian tradition. The first is the 'kingship model', which prescribes that humans are to subdue the earth and have dominion over all things. The locus classicus proposed for this view in classic theology is Genesis 1:18. These authors are justly critical towards this model because it results in a topdown domination of nature by mankind. The authors describe the second model as the 'stewardship model'. This model continues with the structure of 'hierarchical dualism' but further entails that human beings should be responsible caretakers or guardians of creation. They refer to statements of the US Catholic Bishops in 1991 and the Evangelical Lutheran Church in America's in 1993 to prove their statement that this stewardship model is the view held in most mainline Christian traditions. Their assessment is probably correct. However, they argue that although this model is a better articulation of the view of Scripture, it does not delve deeply enough to articulate what the relation between humankind and creation should be. The third model can be described as the 'kinship model'. It sees human beings and the earth with all its creatures intrinsically related as companions in a community of life. This kinship attitude does not measure differences on a scale of higher or lower ontological dignity but appreciates them as integral elements in the robust thriving of a whole. This evaluation of McCormick and Connors provides valuable ethical codes for an ecumenical approach by churches to serve the integrity of creation.

The doctrine of creation is therefore a useful tool in an ecumenical ethics that can be utilised by churches to speak with one voice on human dignity, human rights and ecology with reference to everything these noble ideas in Christian ethics involves. Another biblical concept that can be utilised in an ecumenical ethic in South Africa today is the idea of the reign of God.

\section{The idea of the reign of God}

The theology of the Kingdom of God has become an important paradigm in recent Reformed theological research in South Africa. This research departs from the notion that the concept of the Kingdom can be regarded as one of the central themes in the biblical revelation. This point of departure is founded on the prominent studies of Ridderbos (1950), Bright (1973), Küng (1992) and Welker (2013). The concept 'Kingdom of God' and all its varied expressions are all about the present and the future reign of God. The reign of God as a present reality finds concrete expression in the 
coming and teaching of Christ. Welker (2013:209) deals with this issue in depth in his recent publication. He indicates that through Jesus Christ and the power of the divine Spirit, God's reign reveals the loving, preserving, salvific and uplifting activity of the Creator and the Triune God. Over and against the notion of understanding God's revelation in Christ through the power of the Spirit from the perspective of 'creation' and 'Creator', he posits that the resurrected and exalted Christ is not present apart from the Holy Spirit and that it is through the divine Spirit that he includes his witness in his post-Easter life. The reign of Christ is executed in his threefold office or the threefold 'gestalt' of the reign of Christ or the threefold 'gestalt' of the reign of God. ${ }^{4}$ This threefold gestalt of the reign of Christ generates the power of the Spirit, the formation of the church and Christian action in public life. The threefold office of Christ constitutes the organic relationship between the reign in concrete, realistic terms in the public sphere (Welker 2013:247). ${ }^{5}$

The Kingdom is therefore a kingdom with a unique moral nature and quality. This unique moral character is determined by the law of the Kingdom that is written on the 'heart of every human being'. Calvin (Institutes 1559: 2:7:1) reiterated the reality of the moral conscience given to all people as a result of God's general goodness. This moral conscience can be described as a moral law. The topic has been dealt with in a previous section. Furthermore, the moral quality of the Kingdom can be summarised in the words of the great commandment. It is a kingdom of justice in the widest sense of the word. This quality is like a diamond with many facets such as, amongst others, the love of God and fellow human beings, reconciliation, justice, transformation of the discriminatory society, upliftment of the poor and the destitute, hope and peace. It is indeed a peaceable kingdom as Hauerwas (1983) posits in his seminal work on the subject. The reign of God becomes visible where love vindicates hatred and enmity and where people are reconciled over and above the social divisions caused by humankind's inclination to prejudice. It is these qualities that should be pursued by the people of the Kingdom.

The biblical concept of the reign of God offers a feasible theological paradigm for constructive civil action by churches on the basis of an overlapping ethical consensus in an ecumenical ethic. The idea of the reign of God enables Christians and churches to partake as transmitters of the morality of this reign into society. The government should always be reminded of their calling as a moral agent within the parameters of the reign of God and their responsibility to exert justice for all and their special calling to take the plight of the poor seriously and to improve their condition with

4.Welker prefers to speak of the 'threefold office' rather than the 'three offices of Christ' because the offices interpenetrate each other and are subsequently perichoretically connected.

5.Welker (2013) notes:

'Christ's royal office or the royal gestalt of God's reign both inside and outside of churches exhibits an unstoppable dynamic; a grand current of what individually are often quite inconspicuous deeds of free, creative self-withdrawal, love, acceptance, often quite inconspicuous deeds of free, creative self-withdrawal, love, acceptance,
loving concern, and forgiveness sets into motion enormous emergent processes and loving concern, and forgive
developments'. (p. 247) sound and responsible legislation and economic policies. In their collective testimony towards the authorities of the day in South Africa, churches can speak with one voice in order to augment the moral directives of the reign of Christ such as justice, nation-building, peace-making, liberation, reconciliation, transformation and hope for the vulnerable.

\section{The idea of Christology}

Van de Beek (2002:165) calls this age the 'age of Christology'. The question of Jesus to his disciples in Matthew 16:15 still reverberates in theology today - particularly in the postapartheid South Africa with its deep need for reconciliation, forgiveness and the total transformation of society. Is Jesus of Nazareth relevant at all as he is portrayed in long traditions of theology, worship, liturgies, creeds and confessions over many years and in many contexts in the process of the transformation of the South African society, and can Christology be another area of overlapping consensus for an ecumenical ethic in South Africa?

The answer to this question in South Africa today must take into account that Christian Christologies have indeed a long history of development. Because of the different hermeneutical approaches, it is impossible to speak of the Christian Christology, the Ecumenical Christology or even the Reformed Christology. The historical survey of Ford and Higton (2002) introduces the scholar to a variety of conceptions about the person, work and relevance of Jesus of Nazareth. However, all Christologies say that we know God, in the deepest sense of the word, in Jesus. Van de Beek (s.a. 13) rightly points out that the Christian faith stands or succumbs by this notion. However, he reminds us also that in the range of Christologies over the centuries, two broad movements can be identified, namely the high Christology, speaking of the post-Easter Jesus as God, and the low Christology, focusing on his pre-Easter humanity alone. A close reading of the work of Ford and Higton (2002:303) reveals that it is the latter that has become very popular in the age of modernism and post-modernism.

These two broad movements determine Christology in South Africa also. However, in the South African discourse, many conceptions of Jesus emerged within the framework of the two broad historical movements over the years of the struggle, the liberation, the quest for spirituality and the theology of reconstruction. In a recent thought-provoking and informative article, Mouton and Smit (2009:247) investigated four of the dominant discourses on Jesus in contemporary South Africa. They surveyed the discussions of Jesus in popular news and newspaper debates, academic circles and scholarships, the worship and spirituality of congregations and believers and public opinion about social and political life. After reviewing a huge corpus of South African literature regarding concepts about Jesus, they ask the question whether Jesus was lost in translation in the South Africa of recent times.

Taking into account the extensive research of Mouton and Smit (2009), this investigation endeavours to make a case for 
a Christology of the reign of God as explained earlier as a further foundation for a possible ecumenical ethics conducive to the witness of churches in South Africa today. The reign of God as a present reality finds concrete expression in the coming and teaching of Jesus as the Christ. He stood up against the temptations of Satan, he rules over sickness and even death and he defies the power of nature. He transforms the powers around him. He also set the plan for the transformation of society by issuing the 'Magna Charta of the Kingdom' in the Sermon on the Mount. Under his ministry, people transformed their lives and followed him. Christ is the champion of love, peace, transformation and reconciliation, and whatever differences there may exist between ecclesiastical traditions on Christology; these principles are universal in Christianity.

The transformed people are the first indicators of the Kingdom as a present reality. As a result of Christ's transforming work, a new community was formed, namely the ecclesia. Therefore, the church can be regarded as the second sign of the transforming work of Jesus, and therefore a visible indicator of the Kingdom (Heyns 1977:23). The relation between the transforming work of Jesus and the formation of churches is important for the understanding of the transforming work of Jesus today. The Kingdom is all about the establishment, recognition and eventual vindication of the reign of God by way of the sacrificial death and atonement by Christ. The church is a visible sign of this reign, but also its herald. The church consists of transformed people and becomes the universal community of believers. This universal community manifests in the local congregations like Jerusalem, Antioch and Ephesus. The local congregation bears all the attributes of the universal church. It has the same responsibility, namely to embody the reign of God and everything it represents, such as love, hope, peace and joy. The word servanthood captures the essential role of the church (Bonhoeffer 1995:47; Stackhouse 1995:26). The churches as congregations of believers, as well as individual Christians, are servants in service of the Kingdom of God. In addition to being the sign of the Kingdom, the church is also the 'spear point' of the Kingdom and the promoter of the transforming work of Jesus. The church should embody, reveal and promote the reign of God according to the Magna Charta of the Kingdom as Jesus explains it in the Sermon on the Mount. The transforming work of Jesus should be continued in the transforming work of the church - universal and local. For this reason, the Spirit of God comes on Pentecost to inspire and assist the church in this God-given task according to the model of transformation given by Jesus. The transforming work of Jesus evokes the transforming work of the church within the broad process of the presentistfuturist Kingdom of God. Therefore, churches should be always ready to stand up against oppression and discrimination and to further the cause of love, peace and reconciliation. They should be the voice of the poor and the vulnerable irrespective of variations of Christological positions. Christology and the ecclesiology flowing from it are potent motivation for churches to speak with one voice when it comes to love, peace and reconciliation.

\section{Conclusion}

A viable and sustainable ecumenical ethic is possible when churches endeavour to reach an overlapping consensus on the ideas of the revelation of God, the creation and creational gifts, the reign of God and Christology. This ecumenical ethic can lead churches to speak with one voice to the authorities in South Africa when addressing major ethical problems such as sexism, racism, xenophobia, homophobia and a better life for the poor and the vulnerable. Instead of flying in the orbit of their own denominational issues, churches in South Africa should engage in vigorous ecumenical dialogue with the aim of speaking with one voice about the pressing and troubling moral concerns in South Africa today.

\section{Acknowledgements Competing interests}

The author declares that he has no financial or personal relationships which may have inappropriately influenced him in writing this article.

\section{References}

Arner, N., 2016, 'Prospects for an ecumenical ethics: Signs of common moral witness', Presentation at the Society of Christian Ethics, 8 January 2016.

Banda, F., 2005, Women, law and human rights: An African perspective, Hart Publishing, Oxford.

Barth, K., 1932, Die Kirchichle Dogmatik, Die Lehre vom Wort Gottes 1/1, Chr. Kaiser Verlag, München.

Barth, K., 1961, Church dogmatics, vol. III: The doctrine of creation, part 4, transl. A.T. Mackay et al., Clark, Edinburgh.

Berkhouwer, G.C., 1957, Dogmatische studiën: De mens het beeld Gods, Kok, Kampen.

Bonhoeffer, D., 1995, Ethics, Simon \& Schuster, London.

Bright, J., 1973, The Kingdom of God, Abingdon Press, New York.

Bruce, F.F., 1988, 'Biblical Criticism', in S.B. Ferguson, D.F. Wright \& J.I. Packer (eds.), New dictionary of theology, pp. 93-96, Inter-Varsity Press, Leicester.

Brueggemann, W., 1999, A theological introduction to the Old Testament, Abington, Nashville.

Brunner, E. \& Barth, K., 1946, Natural theology, Geofgrey Bless, London.

Bultmann, R., 1963, The history of the synoptic tradition, Blackwell, London.

Bultmann, R., 1967, Jezus Christus en de mythe, Ten Have, Amsterdam.

Calvin, J., 1559 [2008], Institutes of the Christian religion, Hendriksen, Peabody, MA. Derrida, J., 1997, Of grammatology, transl. G.C. Spivak, John Hopkins University Press, Baltimore, MD.

Derrida, J., 2004, 'From outwork, prefacing in dissemination', in R. Drolet (ed.), The postmodernism reader, pp. 147-153, Routledge, London.

Desilet, G., 2009, 'Heidegger and Derrida: The conflict between hermeneutics and deconstruction in the context of rhetorical and communication theory Quarterly Journal of Speech 77(2), 152-175. http://dx.doi.org/10.1080/0033 5639109383950

Dunn, J.D.G., 2003, Christianity in the making, vol. 1: Jesus remembered, Eerdmans, Grand Rapids, MI.

Efthimiou, M.B., 1994, 'Orthodoxy and the ecological crisis', in D.G. Hallman (ed.), Ecotheology: Voices from South and North, pp. 1-15, WCC, Geneva.

Fairfield, P., 2002, The ways of power. Hermeneutics, ethics, and social criticism, Duquesne University Press, Pittsburgh, PA.

Ford, D.F. \& Higton, M., 2002, Jesus, Oxford University Press, Oxford.

Gadamer, H., 1976, Philosophical hermeneutics, transl. D.E. Linge (ed.), University of California Press, Berkeley, CA.

Grabill, S.J., 2006, Rediscovering the natural law in Reformed theological ethics, Eerdmans, Grand Rapids, MI.

Granberg-Michaelson, W., 1994, 'Creation in ecumenical theology', in D.G. Hallman (ed.), Ecotheology: Voices from South and North, pp. 90-105, WCC, Geneva.

Gudorf, C.E., 2007, 'Violence against women in world religions' in D.C. Maguire \& Sa'Diyya Shaik (eds.), Violence against women in contemporary world religion, pp. 9-29, Pilgrim Press, Cleveland, $\mathrm{OH}$.

Hadsell, H., 2006, 'Ecumenical social ethics now', in R. Gurney, H. Hadsell \& L. Mudge (eds.), Beyond idealism: A way ahead for ecumenical social ethics, pp. 17-29, Eerdmans, Grand Rapids, MI. 
Hauerwas, S., 1983, The peaceable kingdom: A primer in Christian ethics, University of Notre Dame, Notre Dame.

Herholdt, M.D., 1998, 'Post-modern hermeneutics', in S. Maimela \& A. König (eds.), Initiation into theology. The rich variety of theology and hermeneutics, pp. 451-470, Van Schaik, Pretoria.

Heyns, J.A., 1977, The church, NG Kerk Boekhandel, Pretoria.

Huber, W., 2011, 'The dignity of difference - Towards a Christian ethics for pluralistic societies', in L. Hamsen, N. Koopman \& R. Vosloo (eds.), Living theology: Essays presented to Dirk J. Smit on his sixtieth birthday, pp. 427-440, Bible Media, Wellington.

Knight, P., 2003, 'Pragmatism, postmodernism and the Bible as a meaningful public resource in a pluralistic age', in J.M. Court (ed.), Biblical interpretation: The meanings of Scripture - Past and present, pp. 310-325, T \& T Clark, London.

Kuhn, T.S., 1970, The structure of scientific revolutions, The University of Chicago Press, Chicago, IL.

Küng, H., 1992, The church, Burns and Oates, Kent, MI.

Long, V.P., Longman, T., Muller, R.A., Poythress, V.S. \& Silva, M., 1996, Foundations of contemporary interpretation, Zondervan Publishing House, Grand Rapids, MI.

Lyotard, J.F., 1991, The post-modern condition: A report on knowledge, Manchester University Press, Manchester.

Lyotard, J.F., 2004, 'The post-modern condition: A report on knowledge', in R. Drolet (ed.), The postmodernism reader, pp. 123-146, Routledge, London.

Marger, M.N., 1994, Race and ethnic relations. American and global perspectives, Wordsworth, Belmont.

Martinez, P., 1986, 'The right to be human', Evangelical Review of Theology 10(5), 270-276.

McCormick, P.T. \& Connors, R.B., 2002, Facing ethical issues: Dimensions of character, choices and community, Paulist Press, New York.

McGrath, A., 2008, Christian theology: An introduction, Blackwell, London.

Moltmann, J., 1993, God in creation, Fortress, Minneapolis, MN.

Mouton, E. \& Smit, D., 2009, 'Jesus in South Africa - Lost in translations', Journal of Reformed Theology 3(3), 247-273. http://dx.doi.org/10.1163/187251609X 12559402787155

Muller, P., 2002, Die nuwe hervorming, Protea, Pretoria.

Olivier, E., 2011, 'Violence: The church is part of the problem', Verbum et Ecclesia 32(2), 66-70. http://dx.doi.org/10.4102/ve.v32i2.510

Pannenberg, W., 1977, Human, nature, election and history, The Westminster Press, Philadelphia, PA.

Rawls, J., 1993, Political liberalism, Columbia University Press, New York.
Ricoeur, P., 1981, Hermeneutics and the human sciences, transl. J. B. John(ed.), Cambridge University Press, Cambridge.

Ridderbos, H., 1950, De komst van het koninkrijk. Jezus' prediking volgens de synoptische evangeliën, Kok, Kampen.

Schüssler-Fiorenza, E., 1998, Sharing her Word: Feminist biblical interpretation in context, T\&T Clark, Edinburgh.

South African Human Rights Commission, 1999, 'The Braamfontein statement: Racism and xenophobia: A violation of human rights', South African Journal of Human Rights 15, $133 \mathrm{ff}$.

Stackhouse, M.L., 1995, Christian social ethics in a global era. Reforming Protestant views, Abington, Nashville.

Stewart, D., 1989, 'The hermeneutics of suspicion', Journal of Literature and Theology 3(3), 296-307. http://dx.doi.org/10.1093/litthe/3.3.296

Van de Beek, A., 2002, 'Theologen van de twintigste eeuw en de christologie', Acto Theologica 22, 160-175. http://dx.doi.org/10.4314/actat.v22i1.5401

Van de Beek, A., s.a., Jesus kyrios: Christology at the heart of theology, Meinema, Zoetermeer.

Van den Brink, G. \& Van der Kooi, C., 2012, Christelijke Dogmatiek, Uitgeverij Boekencentrum, Zoetermeer.

VanDrunen, D., 2010, Natural law and the two kingdoms: A study in the development of Reformed social thought, Eerdmans, Grand Rapids, MI.

VanDrunen, D., 2014, Divine covenants and moral order: A Biblical theology of natural law, Eerdmans, Grand Rapids, MI.

Vorster, J.M., 2007, Christian attitude in the South African liberal democracy, Potchefstroom Theological Publications, Potchefstroom.

Vorster, J.M., 2014, Christelike etiek in 'n sekulariserende samelewing, AOSIS, Durbanville. http://www.dx.doi.org/10.4102/aosis.ceiss.2014.01

Vorster, N., 2010, 'Are freedom and equality natural enemies? A Christian-theological perspective', The Heythrop Journal, A Bimonthly Review of Philosophy and Theology 51(4), 594-609. http://dx.doi.org/10.1111/j.1468-2265.2010.00576.x

Welker, M., 2013, God the revealed: Christology, Eerdmans, Grand Rapids, MI.

Westermann, C., 1973, Forschung am Alten Testaments: Gesammelte Studien. Band 2, Christliche Kaiser Verlag, München.

Witte, J., 2007, The reformation of rights: Law, religion, and human rights in early modern Calvinism, University Press, Cambridge.

World Council of Churches, 2016, The WCC and ecojustice, viewed 4 August 2016, from http://www.oikumene.org/en/what-we-do/climatechange

Wright, C.J.H., 2004, Old Testament ethics for the people of God, InterVarsity, Leicester. Wüstenberg, R.F., 1996, A theology of life, transl. D. Stott, Eerdmans, Grand Rapids, MI. 